\title{
Chitra indica (Gray 1830) - Narrow-Headed Softshell Turtle
}

\author{
IndRaneIl Das ${ }^{1}$ ANd ShaIlendra Singh ${ }^{2}$ \\ ${ }^{1}$ Institute of Biodiversity and Environmental Conservation, \\ Universiti Malaysia Sarawak, 94300 Kota Samarahan, Sarawak, Malaysia \\ [idas@ibec.unimas.my]; \\ ${ }^{2}$ Center for Herpetology, Madras Crocodile Bank Trust, \\ Post Bag 4, Mamallapuram 603 104, Tamil Nadu, India \\ [shailendra_mcbt@yahoo.com]
}

\begin{abstract}
Summary. - The narrow-headed softshell turtle, Chitra indica (Family Trionychidae), is an extremely large (total carapace length at least $110 \mathrm{~cm}$ ), highly aquatic species. It is widely distributed on the Indian subcontinent. Fish, frog, crustaceans, and mollusks have been recorded as food, the species exhibiting a highly specialized morphology for ambush-feeding. A large clutch, comprising 65-193 eggs, $26.8 \mathrm{~mm}$ in mean diameter and 10.4 $\mathrm{g}$ in mean mass, is laid at the height of the monsoons in central India, while nesting in northern India, Bangladesh, and Nepal takes place during the low water season. Population sizes are unknown, but the species appears to be threatened by human exploitation and modifications of its riverine habitat.

Distribution. - Bangladesh, India, Nepal, Pakistan. Distributed in the Indian subcontinent from Pakistan through India to Bangladesh.

Synonymy. - Trionyx indicus Gray 1830, Trionyx aegyptiacus indica, Chitra indica, Gymnopus indicus, Aspidonectes indicus, Gymnopus lineatus Duméril and Bibron 1835, Trionyx lineatus.

SuBSPECIES. - None recognized.

Status. - IUCN 2008 Red List: Endangered (ENA1cd+2cd) (assessed 2000); CITES: Appendix II; Indian Wildlife (Protection) Act: Schedule II; Pakistan: Wildlife Protection Act: Schedule III.
\end{abstract}

Taxonomy. - The species was described as Trionyx indicus by Gray (1830) and illustrated in Gray (1831, Plate 80 ), based on water colors executed at the behest of MajorGeneral Thomas Hardwicke (1756-1835), who served in the Bengal Artillery of the East India Company. However, it appears that a syntype too existed at the Royal College of
England, which was destroyed during the air-raids of London during World War II (see Farkas 1994). The type locality was given as "India, fl. Ganges, Penang" (= Pulau Pinang, $05^{\circ} 30^{\prime} \mathrm{N} 100^{\circ} 28^{\prime} \mathrm{E}$, West Malaysia), by Gray (1831), and was restricted to "Fatehgarh, Ganges" $\left(27^{\circ} 22^{\prime} \mathrm{N} 79^{\circ} 38^{\prime} \mathrm{E}\right.$, Uttar Pradesh, northern India) by Smith (1931:162), and

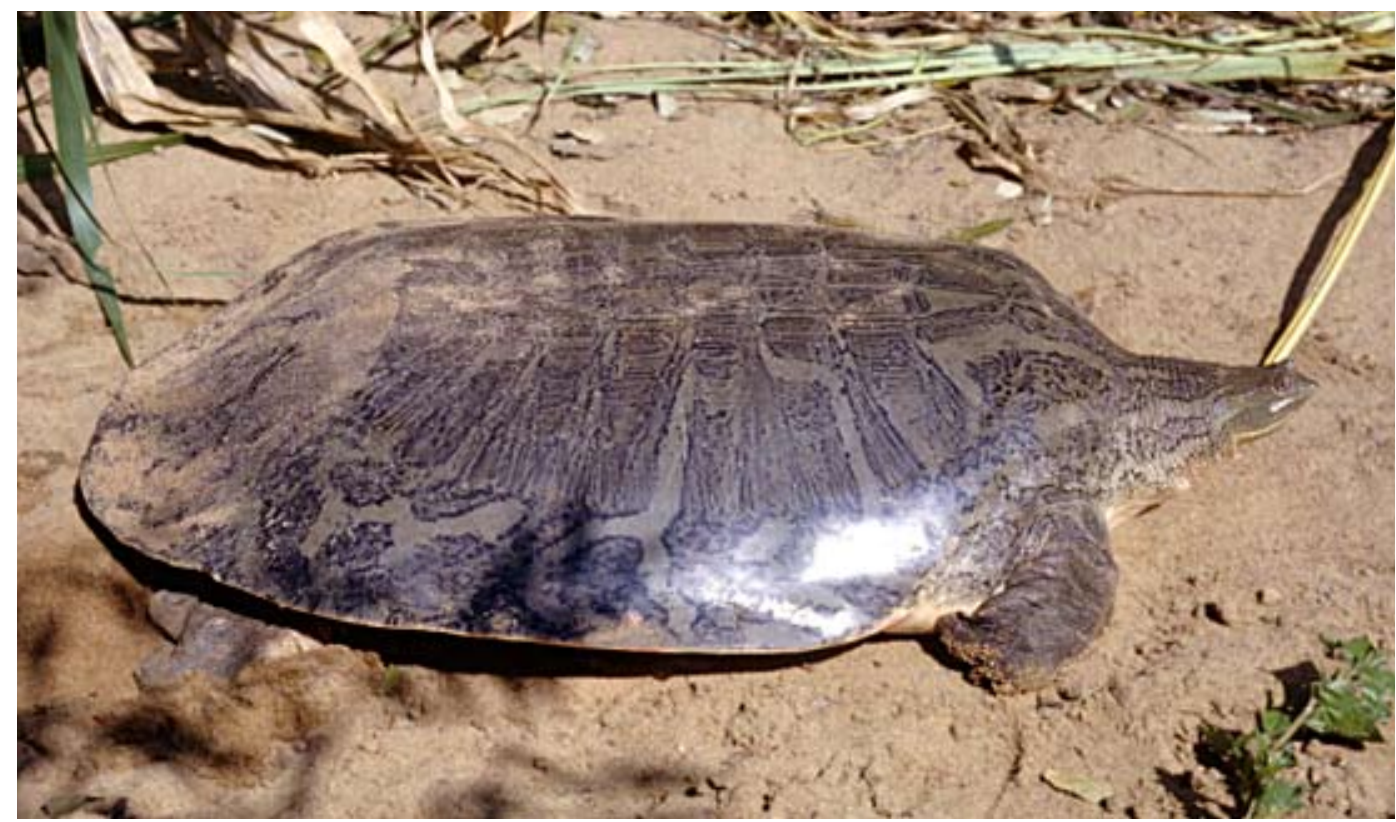

Figure 1. Chitra indica, Chambal River, Rajasthan, India. Photo by Shekar Dattatri. 


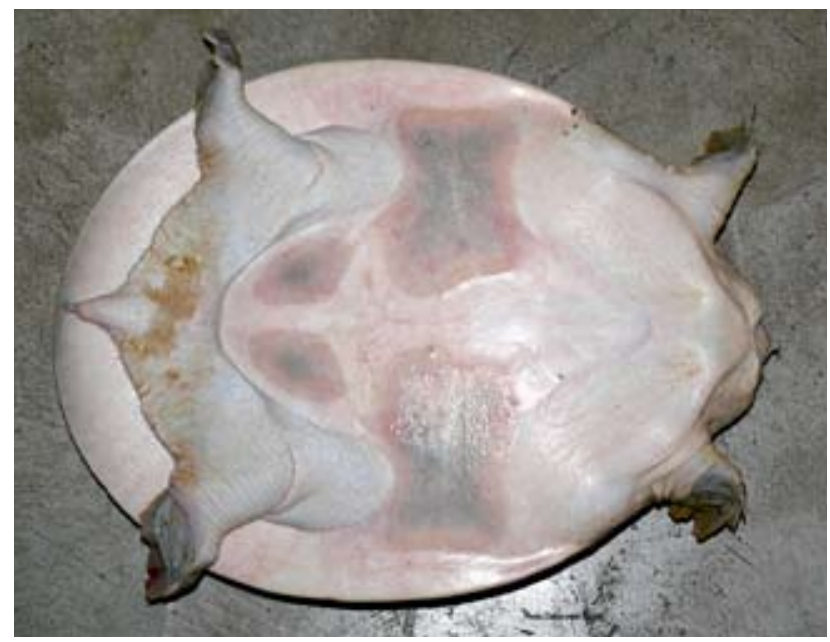

Figure 2. Chitra indica, Assam, India. Photo by Chittaranjan Baruah.

again (although invalidly; see Farkas 1994; Webb 1989) restricted to "Barrackpore (about $23 \mathrm{~km}$ north of Calcutta" (= Barakpur, $22^{\circ} 45^{\prime} \mathrm{N} 88^{\circ} 20^{\prime} \mathrm{E}$, north of Kolkata, India) by Webb (1980).

A name in its synonymy is Gymnopus lineatus Duméril and Bibron 1835. No subspecies have been described and geographic variation is undocumented. The genus Pelochelys is considered sister to Chitra by Engstrom et al. (2002). The placement of these two genera in a tribe (Chitrini), together with Amyda cartilaginea (Boddaert 1770) by Meylan(1987), based on morphological characters, is more controversial, and is not supported by molecular data. The taxonomy of Chitra, including descriptions of new taxa and a detailed description of the morphology and coloration of $C$. indica was presented by McCord and Pritchard (2002). Geographical variation is unstudied, and no subspecies are recognized. However, Rashid (1991) mentioned that individuals from the northern and central areas of Bangladesh are paler in coloration than those from the south.

Description. - Shell widely oval and flattened; eight pairs of costals and four plastral callosities present. A single neural is present between the first pair of costals. Numer-

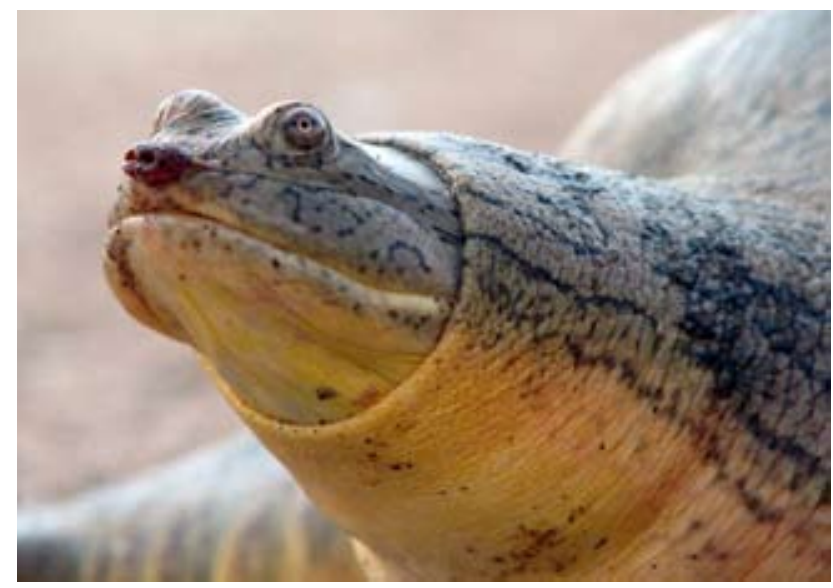

Figure 3. Chitra indica, Chambal River, Uttar Pradesh, India. Photo by Ashutosh Tripathi. ous small tubercles and a vertebral keel are present on the carapace of juveniles. The postorbital bar is twice the orbit diameter. The species has a short fleshy proboscis. The skull is long and narrow, with the nostrils and orbit situated close to the tip. The carapace is dull olive or bluish-gray with a complicated pattern of wavy reticulations; the neck and the outer surfaces of the forelimbs are similarly colored. There is a ' $\mathrm{V}$ ' shaped marking from the nape of the neck to the anterior part of the carapace; juveniles occasionally have four ocelli or numerous black elongated markings on the carapace. The plastron is cream or pale pink. Annandale and Shastri (1914) reported that "its carapace alone may attain a length of at least six feet" [ $183 \mathrm{~cm}]$, although this may have been an exaggeration. The largest specimen in a museum collection is MNHN 1880-182, its bony disk measuring 55.0 $\mathrm{cm}$, with an estimated carapace length (CL; bony disk plus leathery shell) of $71.5 \mathrm{~cm}$, and one in the field measured $110.0 \mathrm{~cm}$ in total CL (bony disk plus soft leathery shell); the bony disk is typically $72.3-79.9 \%$ of the total CL; $n=$ 4, I. Das, unpubl. data).

Hatchlings have a CL of 39-40 mm and a mass of 7-10 $\mathrm{g}$ (Sachsse 1971). Parshad (1914) found a hatchling that measured 29 × $33 \mathrm{~mm}$.

Adult males possess comparatively longer tails, with thicker bases, than females. In Bangladesh, females attain a greater average size than males. Rashid (1991) and Rashid and Swingland (1997) measured 21 males and the same number of females, dividing each group into "large" and "medium-sized" individuals that may have corresponded, at least roughly, to adult and subadult animals. The large males averaged $55.83 \mathrm{~cm}$ in CL (range 51-61.5 cm), 50.49 $\mathrm{cm}$ in carapace width (range $47-57 \mathrm{~cm}$ ), and had an average mass of $17.3 \mathrm{~kg}$ (range $17-25.6 \mathrm{~kg}$ ). The large females averaged $64.44 \mathrm{~cm}$ in CL (range 56-79.5), $55.82 \mathrm{~cm}$ in carapace width (range $50-61.5 \mathrm{~cm}$ ), and mass of $30.2 \mathrm{~kg}$ (range 14.5 to $57 \mathrm{~kg}$ ). The "medium-sized" males averaged $42.26 \mathrm{~cm}$ in CL (range $32-49 \mathrm{~cm}$ ), $38.16 \mathrm{~cm}$ in carapace width (range $28.5-39 \mathrm{~cm}$ ), and mass of $8.5 \mathrm{~kg}$ (range $3-14.25 \mathrm{~kg}$ ). The "medium-sized" females averaged $41.32 \mathrm{~cm}$ in CL (range $30-51.2 \mathrm{~cm}$ ), $41.42 \mathrm{~cm}$ in carapace width (range 26.2-47

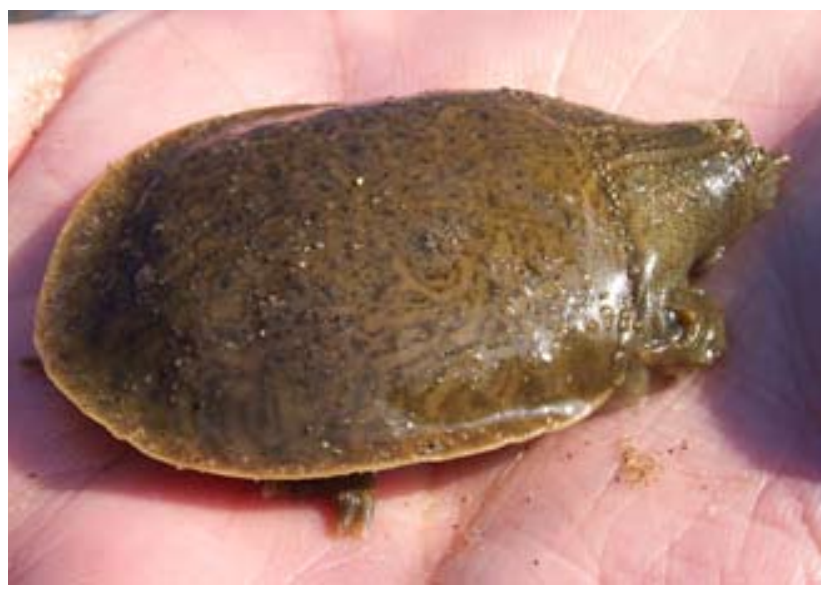

Figure 4. Chitra indica hatchling, Ganga River, Uttar Pradesh, India. Photo by Ashutosh Tripathi. 


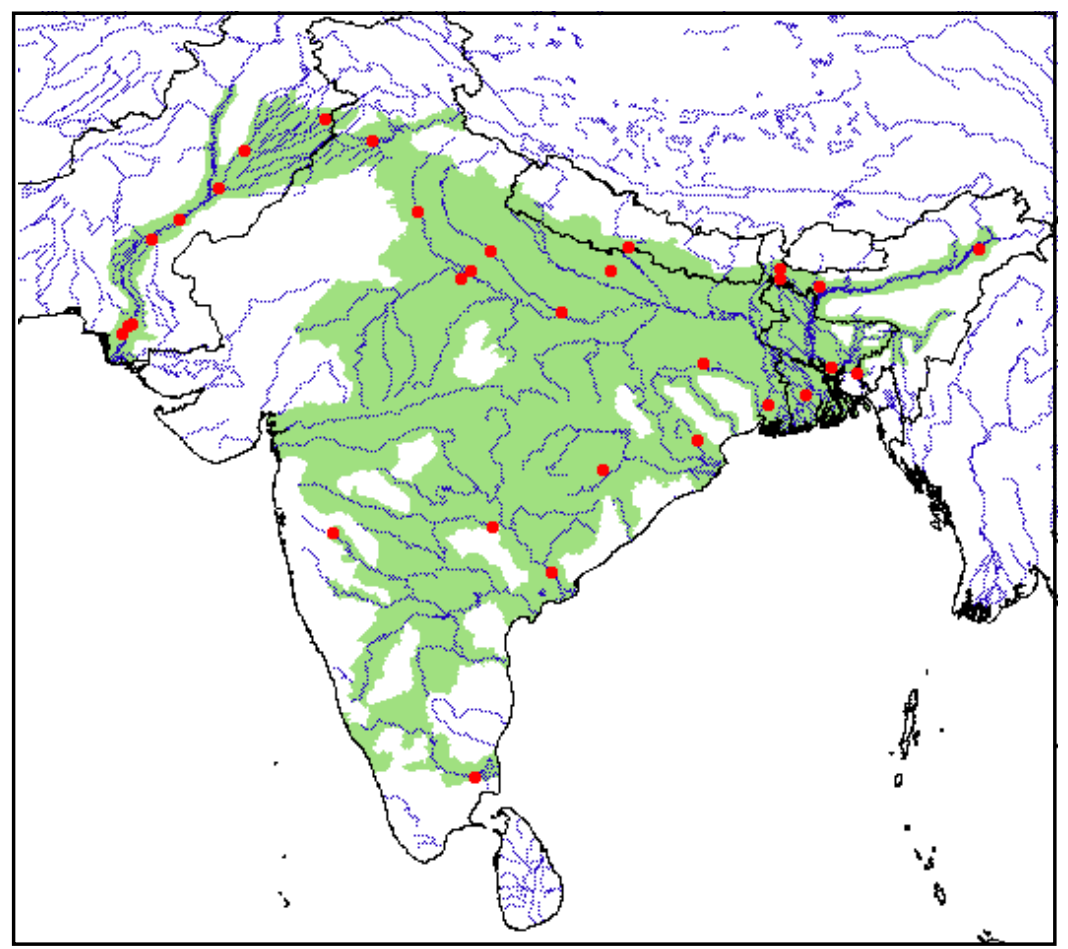

Figure 5. Distribution of Chitra indica in the Indian subcontinent. Red points = museum and literature occurrence records based on Iverson (1992) plus more recent and authors' data; green shading = projected distribution based on GIS-defined hydrologic unit compartments (HUCs) constructed around verified localities and then adding HUCs that connect known point localities in the same watershed or physiographic region, and similar habitats and elevations as verified HUCs (Buhlmann et al., in press), and adjusted based on authors' data.

$\mathrm{cm}$ ), and mass of $10.9 \mathrm{~kg}$ (range $2.8-13.2 \mathrm{~kg}$ ). It seems possible from these data that Rashid and Swingland (1997) used an arbitrary threshold of approximately $14.5 \mathrm{~kg}$ for defining "large" and "medium-sized" animals. However, since Schleich and Kästle (2002) claimed that sexual maturity is reached at $45-55 \mathrm{~cm}$ and $12-16 \mathrm{~kg}$ body mass, these samples could reflect adult versus subadult turtles. Shafi and Quddus (1976) suggested that some individals reach $265 \mathrm{~kg}$.

In Nepal, Shrestha (1996a, b) reported that the average CL of "spot samples" of turtles caught by fishermen near Patharbojhi in 1994 was $80 \mathrm{~cm}$, although most of the specimens caught around Chisapani were juveniles measuring only $8-17.5 \mathrm{~cm}$.

Genetics of Chitra indica and other species of Chitra and related trionychids have been analyzed by Engstrometal.(2002) and Engstrom and McCord (2002). The karyotype was reported as $2 n=66$ from an individual from Shillong, Meghalaya State, northeast India (Sharma and Nakhasi 1981).

Distribution. - The Indiannarrow-headed softshell turtle is widespread in South Asia, its distribution including the rivers Indus, Ganga, Godavari, Coleroon, Mahanadi, and Padma in India, Pakistan, Bangladesh, and Nepal (Das 1995).

The distribution on peninsular India is extensive, but apparently localized and patchy, presumably the result of its highly specialized habitat requirement (perhaps in addition to its large body size, and hence, both rarity due to historical exploitation and the reluctance of some collectors to acquire large specimens (see Lehn et al. 2007). Webb (1981), in reviewing its distribution in the Indian Peninsula, found records from Dhond, near Pune, Maharashtra State, and the species forms the model for temple carvings deep in the south, in the Chennai region (see Annandale 1914), and the Madras Government Museum has a skeleton from Coleroon River in Tamil Nadu (I. Das, unpubl. data).

There are surprisingly few published records from the Brahmaputra drainage. Choudhury (1990) reported one caught from the Lohit River in upper Brahmaputra, and Datta (1997) from Fakirgunj Ferryghat, Dhubri district, in lower Assam. A recent guide to the herpetofauna of northeast India lists this species from Brahmaputra and its tributaries, while specifying it is "very rare" (Ahmed et al. 2009). Inglis et al. (1920) recorded the species from Jalpaiguri District of northern West Bengal State, that helps close the distributional gap between these eastern records and those to the west from the Ganga River. Sharma and Nakhasi (1981) reported the species from Shillong, Meghalaya State, northeast India. Since the locality lies at an elevation of ca. $1500 \mathrm{~m}$ above sea level (asl) (rising to $1961 \mathrm{~m}$ asl at Shillong Peak) and has no wide rivers with sandy banks, the record may represent a trade-derived animal. The record from the coastal locality of Goa in the parasitological literature by de Mello et al. (1917), may similarly refer to an animal from trade, or perhaps a misidentification of Pelochelys cantorii.

In Pakistan, its distribution is extensive in the Indus and its tributaries, including Ravi (Mirza and Ali 1972; Khan 2006; Akbar et al. 2006).

The species occurs in all the major rivers of Bangladesh, i.e., the Padma, Jamuna, Meghna, Bhairab, Brahmaputra and Dholeswari rivers (Khan 1987; Rashid 1991; Rashid and Swingland 1997). 
In Nepal, Shrestha (1996a,b) reported populations in the Patharbhoji section of the Grewa River, and that it was one of the most common species in the Karnali area. Overall, the species was described as a common local migrant in Nepal. Schleich and Kästle (2002) mentioned its occurrence in the central and eastern Terai of Nepal; as well as a maximum altitudinal record of $80 \mathrm{~m}$ asl.

Habitat and Ecology. - Optimal habitat is moderate to large rivers, with low turbidity and sandy bottoms. Prashad (1914) obtained remains of fish, frog, and mollusks from the digestive tract of a specimen, and it appears that the species forages by ambush-feeding (Pritchard 1984), burrowing in the substrate with only the tip of the snout exposed, to catch passing prey. Small fish are sucked in head- or tailfirst, while larger ones are swallowed gradually (Sachsse 1971); fish too big to be swallowed are stripped of flesh. The stomachs of seven Bangladesh specimens contained only animal matter, including fish bones and scales, mollusk shells, crab carapaces and legs, shrimp carapaces and legs, and unidentified vertebrate muscle tissue (Rashid and Swingland 1997). Hossain and Sarker (1995) examined the stomach contents of six wild-caught turtles, and reported a dominance of mollusks, including Pila globosa, Unio bengalensis, Achatina fulica and Bellamya spp. (45.7\% of total weight), fishes (32.3\%), unidentified animals (12.6\%), and crustaceans, including crabs, Portunus sp. and prawns, Macrobrachium sp. (9.3\%).

When handled, it has been said that this turtle sometimes shoots out its head and neck, but only striking with its snout, rather than biting, and known to damage fishing boats (Chaudhuri 1912; Ahmad 1955). A strike by an adult male of this species is known to have broken the collarbone of a former poacher; serious injuries on the faces of others are also known from the Ganga River, near Kanpur (S. Singh, pers.obs.). It can also produce an musky odor when handled (Sachsse 1971; Khan 2006). Others have reported that it can inflict severe bite injuries (Satyamurti 1962; Rashid and Swingland 1997).

In the Chambal region (the Ganga River system) of central India, eggs are laid between the end of August and mid-September at the height of the monsoons (Bhaduria et al. 1990). These authors provide the following data. The nest is flask-shaped and excavated in sand or sandy loam, and the egg chamber measures $15 \times 23 \mathrm{~cm}$ in diameter. Nests are located 8-135 $\mathrm{m}$ from the water's edge. Eggs are spherical, brittle-shelled, 25.4-28.2 (mean 26.8) mm, weighing $10.0-18.0$ (mean 10.4) g. The mean clutch size of 10 nests was 118 eggs, the range 65-187. The incubation period at $25.5-36.0^{\circ} \mathrm{C}$ was $40-70$ days (mean 55). In a recent survey (June to August 2008) by S. Singh and A. Tripathi, 10 nests, comprising 1000+ eggs, were collected from a ca. $4 \mathrm{~km}$ stretch of the Ganga River near Farrukhabad District, and placed in riverine hatcheries. Six nests were found in July and four in August. Monsoonal rains started at this locality in early June. The largest clutch size known for the species is 193 eggs, recorded in September 2008 from the lower Chambal River near Etawah (S. Singh, unpubl. data).
In Bangladesh, the breeding season extends from February to May. Rashid and Swingland (1997) reported that the first clutch may be laid between late February and mid-March, the second between late March and mid-April, and the third between late April and mid-May. Nesting is usually nocturnal, although one individual was observed nesting in daylight, on a high bank of the Ganga River. Nests are excavated to a depth of $18-30 \mathrm{~cm}$ in sandy river banks. A female may deposit 170 eggs in a season, and a $34 \mathrm{~kg}$ female dissected on 26 March contained 90 mature, shelled eggs. Hatching is thought to occur in May and June.

In Nepal, Shrestha (1996b) reported a "stable nesting rate" of up to 20 nesting female Chitra indica on cloudy nights between January and February at Karnali, near Chisapani. The related and ecologically similar Chitra chitra in Thailand may also lay 3-4 clutches annually (Kitimasak et al. 2003). The restricted breeding season in northern areas (e.g., northern India and Nepal) is typical of other turtles, whereby nests are excavated during the low-water season, while hatchling emergence synchronizes with the wet season, typically associated with higher secondary productivity. Southern populations inhabit more aseasonal, tropical or subtropical areas.

Population Status. - Chitra indica does not appear to exist at high densities anywhere at present, nor is there any evidence of former abundance, although Acharji (1958) mentioned that it is "not uncommon in the Gangetic delta". One possible exception could be upstream of the Sukkur Barrage, in the lower reaches of the Indus River, where the species as been reported as the most common among five freshwater turtles (Azam et al.2005). Its specialized dietary and habitat requirements make it especially vulnerable to habitat modifications caused by human activities, and the latter factor can be the cause of its patchy distribution and rarity, even within protected areas (see Mishra et al. 1996). Although large numbers were once caught for food markets in Bangladesh (Rashid and Khan 2000) and in India (I. Das, pers. obs.) in the 1970s and 1980s, this species is at present not encountered in meat markets in these countries.

A few large lakes and slow-flowing small rivers in the Terai (foothill plains of the Himalayas) serve as marginal habitats for this species. Recent captures of specimens of different sizes using set-nets and unbaited hooks in the fast-flowing Ghaghara and Chambal rivers suggest that the species survives and is reproducing in a few rivers, despite heavy hunting pressure and habitat degradation (S. Singh, unpubl. data). During three years of field work in northern India targeting the endangered Batagur kachuga, over 25 live or dead specimens of $C$. indica were examined from rivers such as the Chambal, Ganga, Ghaghra, and Sarju (S. Singh, unpubl. data). Except for one adult, all were either juveniles or hatchlings. Interviews with turtle poachers and fishermen also revealed the species' restricted occurrence either in low numbers or as isolated populations in different stretches of major rivers and their tributaries. The interviews also revealed reductions in volume in local turtle markets compared to about 15 years ago; at present $C$. indica com- 
prises only about $2-3 \%$ of the total softshell turtle market volume (S. Singh, pers. obs.).

Threats to Survival. - Although the meat of this species was reported to be coarse and generally not valued as much as that of the other trionychids during the time of Chaudhuri (1912) and Ahmad (1955), significant numbers of this species were traded in India for its flesh up to the 1980s. The species is now extensively hunted for its calipee, the fibrocartilaginous leathery outer margin of the shell (S. Singh, unpubl. data), and depending on size of the turtle, the calipee may vary from $4-10 \mathrm{~cm}$. After boiling and drying, it is apparently shipped to Bangladesh or Nepal, from where it is exported to other countries, such as China, for the manufacture of traditional medicines and soups. A 650 $\mathrm{g}$ piece of dried calipee can be extracted from a live animal of $30 \mathrm{~kg}$, and a kilo of dried cartilage sells for about Indian Rupees 2000 (approximately US\$ 50) from local turtle traders and about Indian Rupees 3500 (approximately US\$ 87) from middlemen. Eggs and the flesh of this species are also consumed by local riverine communities on the Ganga River.

In Bangladesh, on the other hand, there is much demand for the meat in local markets, and collectors complain about increasing scarcity. Khan (1987) reported that the species was rare in Bangladesh, where it was located when buried in the river substrates and stabbed with iron-tipped spearsticks. Rashid and Swingland (1997) wrote that it was the largest freshwater turtle in Bangladesh, and had recently become uncommon in the south and rarer in the northeast and central regions. The turtles spend the great majority of their time buried in the substrate for ambush-feeding. Bangladesh fishermen take advantage of this habit and utilize lines bearing thousands of unbaited hooks, tied on a line and hanging vertically almost to the river bottom. The hooks catch the turtle's soft parts, and it becomes entangled; later it is collected by pulling the lines during periodic checks, or by diving. They are also occasionally caught in dragnets. Fugler (1984) mentioned export of the species, but Rashid (1991) could discover no evidence of international trade in this species from Bangladesh.

In India, this species is captured with the help of unbaited thousand-hook lines (locally called 'hazara') and also with large seine nets set close to the mouths of rivers, their tributaries and small creeks ('nullahs'). During the monsoon season, fishermen set their nets at the confluence of two waterways, assuming the species to be in the vicinity, for the high concentration of fish as well as comparatively weak current. Turtle poachers also dive and use small iron probes to find the species in the bottom of slow-flowing rivers and backwaters (S. Singh, pers. obs.).

Apparently, large adults are not selectively targeted by poachers, being powerful and known to tear drag and set-nets deployed to capture them. They are also less preferred due to their high fat content, which apparently result in lower quality calipee. Calipee extracted from juveniles is often mixed with that of Nilssonia gangetica, and this chewable cartilage is often eaten.
In parts of Nepal, Chitra is considered to be a delicacy, and the dried bones and meat are used to reduce viral infections. Apart from the directed catch, there is considerable incidental capture of Chitra in Nepal (Shrestha 1996a, b).

Extensive river development throughout the range of the species, including damming of rivers, deforestation, aquatic pollution, silting of riverine ecosystems, and overfishing in large parts of its range (Choudhury and Bhupathy 1993; Shrestha 1997) are some factors suspected to affect the survival of this species.

Protozoan infestations have been reported by several authors, including Simondia metchnikovi by Simond (1901) and Anaplasma sp. by de Mello et al. (1917).

Conservation Measures Taken. - The narrow-headed softshell turtle is listed as Endangered on the IUCN Red List, and in Schedule II of the Indian Wildlife (Protection) Act of 1972, as well as in the Red Data Book for Nepal (Shah and Tiwari 2004). In Pakistan, the Wildlife Protection Acts of Punjab and the Northwest Frontier Province lists the species in Schedule III (Noureen et al. 2008).

This is one of several freshwater turtles receiving attention from a conservation project initiated by the Government of India along the Ganga River. The project protects both nesting grounds and the turtles themselves from exploitation, besides collection of eggs from the wild for artificial incubation.

The species occurs in several riverine protected areas in India, notably, the important tri-state National Chambal Sanctuary. It has also been observed in the following protected areas: Katerniaghat Sanctuary, Geruwa River, Bahraich district, Uttar Pradesh, Indo-Nepal border; Son Gharial Sanctuary, Son River, Madhya Pradesh; Hastinapur Sanctuary, Ganga River, near Bijnore district, Uttar Pradesh; and Turtle Sanctuary, Ganga River, Varansi, Uttar Pradesh (S. Singh, pers. obs.).

Conservation Measures Proposed. - Upgrading to Schedule I of the Indian Wildlife (Protection) Act and inclusion in the schedules of the wildlife laws in the other countries where the species occurs (e.g., Bangladesh, Pakistan, and Nepal) are recommended. The trade in this species needs to be more carefully monitored, and if needed, controlled.

Captive Husbandry. - Captive husbandry presents challenges. Chitra indica is an extremely aquatic and physically delicate species, and this, combined with its large size, results in relatively few specimens reaching food markets alive. Instead, they are butchered when caught (or when they die). Among turtles caught for sale alive as exhibit animals, individuals are also often so traumatized and physically abraded by capture and transportation (not to mention having often been impaled by spears used for locating them in bottom substrates) before they reach their captive destination that they do not live long. In captivity, a deep layer of clean sand should be provided so that the turtles can burrow out of sight, and they need to be kept separate from turtles of other species. Often, only live fish are accepted at first, but established captives will also feed on dead fish (I. Das, unpubl. data). Sachsse (1971) fed the 
planktonic crustaceans Daphnia magna, blood worms, Chironomus spp. and Colethra spp., to his hatchlings and juveniles in captivity, besides "parts of terrestrial and aquatic vertebrates" and several species of fish, but they would not accept aquatic snails.

Current Research. - A research and conservation project for this species was initiated in 2006 under the TSA/MCBT Indian Turtle Conservation Programme and is being implemented to document the current populations of this species through extensive statewide surveys and trade investigations, as well as commencing a pilot head-start program. These actions are also supported in the "Conservation Action Plan for Endangered Freshwater Turtles and Tortoises of India" (CFH/MCBT 2006). Status surveys for this species comprise field visits and sampling habitats previous reported to support the species, in addition to nest collection and counts, and interviews in communities to confirm the presence or absence of the species. Services of former poachers have been enlisted to evaluate the current and past trade and volume. Nests collected during the project are being transferred to in-situ riverine hatcheries until hatching. Most hatchlings will be released with coded wire tags after a few months while a small number will be kept for further studies and for developing assurance colonies. Hatchling survivorship and migration studies using radiotelemetry are being planned.

Acknowledgments. - Our work was supported by the Centre for Herpetology, Madras Crocodile Bank Trust, and Universiti Malaysia Sarawak. We thank Hidetoshi Ota for the karyotype paper,Peter C.H.Pritchard for his unpublished data on this species, Genevieve V.A. Gee for reading a draft manuscript.R.Asokan, Madras Government Museum and G. Ramakrishna and B.C.H. Murthy permitted the examination of specimens under their care. Saibal Sengupta helped with a critical reference. Special thanks go to the Turtle Survival Alliance and Cleveland Metroparks Zoo and Cleveland Zoological Society for supporting the current Chitra project in India. We thank Shekar Dattatri, Chittaranjan Baruah, and Ashutosh Tripathi for providing the images.

\section{LITERATURE CITED}

ACHARJ, M.N. 1958. On a collection of chelonians and snakes from Chota Nagpur, Bihar. Records of the Indian Museum 53(3/4):383-392.

Ahmed, M.F., Das, A. And DutTA, S.K. 2009. Amphibians and Reptiles of Northeast India. A Photographic Guide. Aaranyak, Guwahati. 169 pp.

AHMEd, N. 1955. On Edible Tortoises and Turtles of East Pakistan. Directorate of Fisheries. Government of East Bengal, Dacca, 25 pp.

Akbar, M., MushtaQ-ul-Hassan, M. and Zaib-u-Nisa. 2006. Distribution of freshwater turtles in Punjab, Pakistan. Caspian Journal of Environmental Sciences 4(2):142-146.

Annandale, N. 1914. Some general considerations. In: Relics of the worship of mud-turtles (Trionychidae) in India and Burma. Proceedings of the Asiatic Society of Bengal 10:136-137.

Annandale, N. AND Shastri, H. 1914. Relics of the worship of mud-turtles (Trionychidae) in India and Burma. Proceedings of the Asiatic Society of Bengal 10:131-135.

Azam, M.M., Muhammad, S.F., and Saifullah. 2005. Some observations on the distribution and abundance of freshwater turtles in the river Indus. Records of the Zoological Survey of Pakistan 16:46-51.

Bhaduria, R.S.,PAI,A., AND Basu, D. 1990. Notes on habitat, nesting and reproductive adaptations of the narrow-headed softshell turtle, Chitra indica (Gray), Reptilia: Chelonia. Journal of the Bombay Natural History Society 87:364-367.

Buhlmann, K.A., Akre, T.S., Iverson, J.B., Karapatakis, D., MitTERMEIER,R.A.,GEORGES,A.,RHODIN,A.G.J., VANDIJK,P.P., AND GiBBons, J.W.In press.A global analysis of tortoise and freshwater turtle distributions with identification of priority conservation areas. Chelonian Conservation and Biology 8(2):in press.

CFH/MCBT. 2006. Conservation Action Plan for Endangered Freshwater Turtles and Tortoises of India. Madras Crocodile Bank Trust, Vadanemmeli, 43 pp.

Chaudhuri, B.L. 1912. Aquatic tortoises of the middle Ganges and Brahmaputra. Records of the Indian Museum 7:212-214.

Choudhury, A.U. 1990. Turtles recorded in Dibru-Saikhoa Wildlife Sanctuary, Assam. Journal of Ecological Society, Pune 8:33-39.

Choudhury,B.C. ANd Bhupathy,S.1993.Turtle Trade in India:AStudy of Tortoises and Turtles. TRAFFIC India, World Wide Fund for Nature- India and Wildlife Institute of India, New Delhi, 50 pp.

DAs, I. 1995. Turtles and Tortoises of India. World Wide Fund for Nature- India/Oxford University Press, Bombay, 176 pp.

DatTA, S. 1997. Freshwater turtles and land tortoises of Dhubri District. Zoos' Print 12(6):1-4.

de Mello, I.F., De SA, B., de Sousa, L., Dias, A. And Noronha, R. 1917. Hematozoaires et pseudo-hematozoaires de 'IndePortugaise. Anais Scient da Faculd. de Medec do Porto 3:5-24.

Duméril, A.-M.-C. And Bibron, G. 1835. Erpétologie Générale ou Histoire Naturelle Complète des Reptiles. Vol. 2. Librarie Encyclopedique de Roret, Paris, 680 pp.

Engstrom, T.N. AND McCoRd, W.P. 2002. Molecular support for the taxonomic conclusions of McCord and Pritchard (2002), regarding Chitra. Hamadryad 27(1):57-61.

Engstrom, T., ShafFer,H.B., ANd McCord, W.P. 2002. Phylogenetic diversity of endangered and critically endangered southeast Asian softshell turtles (Trionychidae: Chitra). Biological Conservation 104:173-179.

FARKAS, B. 1994. Notes on the type and type locality of the narrowheaded softshell turtle, Chitra indica (Gray, 1831). Miscellanea Zoologica Hungarica 9:117-119.

FugLer, C.M. 1984. The commercially exploited Chelonia of Bangladesh: taxonomy,ecology,reproductive biology and ontogeny. Fisheries Information Bulletin BGD/79/015, 2(1):1-52.

Gray, J.E. 1830. A Synopsis of the Species of the Class Reptilia. In: Griffith, E. (Ed.). The Animal Kingdom Arranged in Conformity with its Organization, by the Baron Cuvier, with Additional Descriptions of all the Species Hitherto Named, and of many not before Noticed.Vol.9.Reptilia,Supplement. Whittaker, Treacher, and Co., London, $110 \mathrm{pp}$.

GrAY,J.E. 1831. Illustrations of Indian Zoology, chiefly selected from the collection of Major-General Hardwicke. Vol. I, Part 8, pl. 80. London: Treuttel, Wurtz, Treuttel, Jun. and Richter.

HanfeE, F. 1995. Notes on freshwater turtle exploitation, Uttar Pradesh, India. TRAFFIC Bulletin 15(3):120-121.

HoSSAIN,M.L. ANDSARKER,M.S.U.1995.Observations on the narrowheaded softshell turtle (Chitra indica) in Bangladesh. Journal of the Bombay Natural History Society 92(3):423-426.

Inglis, C.M., Travers, W.L., O’Donel, H.V. and Shebbeare, E.O. 
1920. A tentative list of the vertebrates of the Jalpaiguri District, Bengal. Journal of the Bombay Natural History Society 27(1):151-162.

IVERSON,J.B. 1992.ARevised Checklist with Distribution Maps of the Turtles of the World. Richmond, IN: Privately printed, 363 pp.

KHAN,M.A.R.1982.Chelonians of Bangladesh and their conservation. Journal of the Bombay Natural History Society 79(1):110-116.

KHAN, M.A.R. 1987. Bangladesher Bonnyoprani. Vol. I. Urochor o Shorishrip. Bangla Academy, Dhaka, 169 pp.

Khan, M.S. 2006. Amphibians and Reptiles of Pakistan. Krieger Publications, Malabar, Florida, 328 pp.

KitimasaK, W., Thirakhupt, K., and Moll, D.L. 2003. Captive breeding of the Siamese narrow-headed softshell turtle Chitra chitra Nutphand, 1986 (Testudines: Trionychidae). Thai Journal of Agricultural Science 36:141-154.

LEHN, C., DAs, I., Forstner, M.R.J. AND BRown, R.M.2007.Responsible vouchering in turtle research: an introduction and recommendations. In: Shaffer, H.B., FitzSimmons, N.N., Georges, A. and Rhodin,A.G.J.(Eds). Defining Turtle Diversity. Proceedings of a Workshop on Genetics, Ethics, and Taxonomy of Freshwater Turtles and Tortoises, Cambridge, Massachusetts, 8-12 August 2005. Chelonian Research Monograph 4:147-156.

MCCORD, W.P. AND PRITCHARD, P.C.H. 2002.A review of the softshell turtles of the genus Chitra, with the description of new taxa from Myanmar and Indonesia (Java). Hamadryad 27(1):11-56.

Meylan, P.A. 1987. The phylogenetic relationships of soft-shelled turtles (Family Trionychidae). Bulletin of the American Museum of Natural History 186:1-101.

Mishra, S.B., Narain, S. and Chauhan, R. 1996. Study of some fresh water turtles of Panchnada. Journal of Nature Conservators 8(1):121-133.

MirZA,M.R. ANDAli,A. 1972.Amphibians and chelonians of Lahore. Biologia, Lahore 18(1):82-87.

Noureen, U., Braulik, T.G., Arshad, M., and Khan, H.M. 2008. Illegal trade in freshwater turtle parts. Preliminary findings of turtle trade in major barrages and head-works of Punjab.Aresearch report submitted to the Ministry of Environment's Pakistan Wetland Programme, Islamabad, $28 \mathrm{pp}$.

PARSHAD, B. 1914. Notes on aquatic Chelonia of the Indus System. Records of the Indian Museum 10:267-272.

PRITCHARD, P.C.H. 1984. Piscivory in turtles and evolution of the long-necked Chelidae. Symposium of the Zoological Society of London 52:87-110.

RASHID, S.M.A. 1991. On the systematics and ecology of some freshwater turtles of Bangladesh. Unpublished M.Sc. Dissertation, Durrell Institute of Conservation and Ecology, University of Kent, Canterbury, 133 pp.

RASHID, S.M.A. AND KHAN, S.M.H. 2000. Overview of turtle trade in Cambodia.In: van Dijk,P.P., Stuart,B.L., and Rhodin,A.G.J.(Eds.). Asian Turtle Trade: Proceedings of a Workshop on Conservation and Trade in Freshwater Turtles and Tortoises in Asia. Chelonian Conservation Monographs 2, pp. 77-85.

RASHID, S.M.A. AND SWINGLAND, I.R. 1997. On the ecology of some freshwater turtles in Bangladesh. In: Van Abbema, J. (Ed.). Proceedings: Conservation, Restoration, and Management of Tortoises and Turtles - An International Conference. New York Turtle and Tortoise Society, New York, NY, pp. 225-242.

SAChsSE, W. 1971. Beobachtungen an jungen Chitra indica insbesondere zum Beuteerwerb. Salamandra 7(1):31-37.

Schleich, H.H. AND Kästle, W. 2002. Order Chelonia/Testudines (turtles: terrapins and tortoises). In: Schleich,H.-H. and Kästle,W. (Eds). Amphibians and Reptiles of Nepal. Biology, Systematics, Field Guide. Koeltz Scientific Books, Königstein, pp. 501-573.

SHAFI, M. AND QudDus, M.M.A. 1976. Bangladesher matshya swampad (in Bangla) - Part 4. Kasim, kaitta o samudrik kasim. Bangla Academy Bignan Patrika 3(2): 14-36.

SHAH, K.B. AND TiwARI, S. 2004. Herpetofauna of Nepal.AConservation Companion. IUCN Nepal, Kathmandu, 237 pp.

Sharma, G.P. AND NAKHASI, U. 1981. Chromosomes of two species of chelonians (Trionychidae: Reptilia). Chromosome Information Service (30):18-20.

SHRESTHA, T.K. 1996a. New survival of rare chelonians in the altered habitats of Himalayan rivers of Nepal: In: Devaux, B. (Ed.). Proceedings of the International Congress of Chelonian Conservation. SOPTOM, Gonfaron, pp. 52-56.

SHRESTHA, T.K. 1996b. Wetland use, habitat fragmentation and their impacts on turtles in Nepal: In: Devaux, B. (Ed.). Proceedings of the International Congress of Chelonian Conservation. SOPTOM, Gonfaron, pp. 57-61.

SIMOND, P.L. 1901. Sur un haematozoaire endoglobulaire pisnnente des tortues. Comptes Rendus Biologies Paris 53:150-152.

Sмiтh, M.A. 1931. The Fauna of British India, including Ceylon and Burma. Vol. I. Loricata, Testudines. Taylor and Francis, London, $185 \mathrm{pp}$.

WeBв, R.G. 1980. Gray,Hardwicke, Buchanan-Hamilton, and drawings of Indian softshell turtles (family: Trionychidae). AmphibiaReptilia 1:61-74.

WebB, R.G. 1981. The narrow-headed softshell turtle, Chitra indica (Testudines: Trionychidae), in Peninsular India. Records of the Zoological Survey of India 79:203-204.

WebB, R.G. 1989. Chitra indica (Gray 1831). In: King, F.W. and Burke, R.L. (Eds.). Crocodilian, tuatara, and turtle species of the world: A taxonomic and geographic reference. Association of Systematics Collections, Washington, D.C., pp. 110.

\section{Citation Format for this Account:}

DAS, I. AND Singh, S. 2009. Chitra indica (Gray 1830) - narrowheaded softshell turtle. In: Rhodin, A.G.J., Pritchard, P.C.H., van Dijk, P.P., Saumure, R.A., Buhlmann, K.A., Iverson, J.B., and Mittermeier, R.A. (Eds.). Conservation Biology of Freshwater Turtles and Tortoises: A Compilation Project of the IUCN/SSC Tortoise and Freshwater Turtle Specialist Group. Chelonian Research Monographs No. 5, pp. 027.1027.7, doi:10.3854/crm.5.027.indica.v1.2009, http://www. iucn-tftsg.org/cbftt/. 